American Journal of Environmental Sciences 5 (3): 382-386, 2009

ISSN 1553-345X

(C) 2009 Science Publications

\title{
Reduction of Ammonia Volatilization through Mixing Urea with Humic and Fulvic Acids isolated from Palm Oil Mill Effluent Sludge
}

\author{
${ }^{1}$ Shamsuddin Rosliza, ${ }^{1}$ Osumanu Haruna Ahmed, \\ ${ }^{2}$ Nik Muhamad Ab. Majid and ${ }^{3}$ Mohamadu Boyie Jalloh \\ ${ }^{1}$ Department of Crop Science, Faculty of Agriculture and Food Sciences, \\ University Putra Malaysia Bintulu Campus, 97008 Bintulu, Sarawak, Malaysia \\ ${ }^{2}$ Department of Forest Management, Faculty of Forestry, \\ University Putra Malaysia, 43400 UPM, Serdang, Selangor, Malaysia \\ ${ }^{3}$ School of Sustainable Agriculture, University Malaysia Sabah, \\ Locked Bag 2073, 88999 Kota Kinabalu, Sabah, Malaysia
}

\begin{abstract}
Problem statement: Ammonia volatilization from surface-applied urea may be substantial but it is possible to control it by mixing urea with acidic substances such as Humic Acids (HA) and Fulvic Acids (FA). The objective of this study was to compare the effects of urea-HA, urea-FA, ureaacidified $(\mathrm{HA}+\mathrm{FA})$ mixtures on ammonia loss, soil $\mathrm{pH}$, soil exchangeable ammonium and available nitrate accumulation compared to urea alone. Approach: The effects of urea amended with or without HA and FA were evaluated in a laboratory condition using a closed-dynamic air flow system. Ammonia loss, soil $\mathrm{pH}$, soil exchangeable ammonium and available nitrate were determined using standard procedures. Results: Humic acid alone was not effective in controlling ammonia volatilization even though ammonium retention was found to be significantly higher compared to urea alone. Fulvic acid significantly reduced ammonia volatilization by $50 \%$ compared to urea alone. It also caused the highest retention of soil exchangeable ammonium and available nitrate. However, there was no ammonia volatilization with acidified HA and FA. Ammonium and nitrate accumulation for FA was better than acidified HA and FA. Ammonia loss could be reduced by improving ammonium retention. It must be stressed that results obtained in the incubation experiment using an acidic $\left(\mathrm{pH}_{\mathrm{water}}\right.$ 6.32) soil of Typic Paleudults (Bekenu series) may only be applicable to similar acid soils. Conclusion: Urea amended with HA or HA and FA significantly reduced ammonia loss. The outcome of this study might be contributed to the improvement of urea $\mathrm{N}$ use efficiency as well as reducing environmental pollution.
\end{abstract}

Key words: Ammonia volatilization, urea, humic acids, fulvic acids, $\mathrm{pH}$, exchangeable ammonium, available nitrate

\section{INTRODUCTION}

Malaysia is the largest producer and exporter of palm oil in the world ${ }^{[1]}$ and this contributes about U\$ 7.3 billion in export earnings each year ${ }^{[2]}$. With such large production of palm oil there is also abundant byproducts such as Palm Oil Mill Effluent (POME). The POME contains high Bio-chemical Oxygen Demand (BOD) and Chemical Oxygen Demand (COD) which pose a great threat to water environment. Disposal of this highly polluting waste is an economic burden on communities and industries ${ }^{[3]}$ therefore adding value to this waste could be economically viable.
POME could be put into good use in view of its high content of organic matter ${ }^{[1]}$ potentially present in the form of Humic Acids (HA) and Fulvic Acids (FA). In some studies, acidic material such as HA and TSP have been used to reduce ammonia loss from surfaceapplied urea ${ }^{[4-8]}$ but evidence of this type is lacking for POME. These acidic materials lower the soil micro-site $\mathrm{pH}$ immediately around the fertilizer, hence, they reduce the hydrolysis of urea thus reducing the ammonia loss. High total acidity (CEC) associated with $\mathrm{HA}$ aids in retaining $\mathrm{NH}_{4}$ and $\mathrm{NO}_{3}{ }^{[4-7]}$ compounds which are the plant usable form of nitrogen. The exchange capacity of FA is double that of HA due to the

Corresponding Author: Osumanu Haruna Ahmed, Department of Crop Science, Faculty of Agriculture and Food Sciences, University Putra Malaysia Bintulu Campus, Sarawak, Malaysia Tel: +6086855406 Fax: +608685415 
total number carboxyl $(\mathrm{COOH})$ groups present and this also helps to retain more $\mathrm{NH}_{4}$ and $\mathrm{NO}_{3}$. High contents of $\mathrm{NH}_{4}$ and $\mathrm{NO}_{3}$ in soils without good retention may not guarantee plant $\mathrm{N}$ use efficiency because both $\mathrm{NH}_{4}$ and $\mathrm{NO}_{3}$ are prone to leaching ${ }^{[9]}$. The additional loss of $\mathrm{N}$ from soil is caused by the biological transformation of $\mathrm{NH}_{4}$ to $\mathrm{NO}_{3}$ under anaerobic condition and denitrification process of converting $\mathrm{NO}_{3}$ to $\mathrm{N}_{2}{ }^{[9]}$. Inefficient use of urea may cause environmental pollution, monetary loss and poor crop quality. The objective of this study was to compare the effects of urea-HA, urea-FA, urea-acidified (HA+FA) on $\mathrm{NH}_{3}$ loss, $\mathrm{pH}$, exchangeable $\mathrm{NH}_{4}$ and available $\mathrm{NO}_{3}$ accumulation with urea alone. This study may contribute to improvement of urea $\mathrm{N}$ use efficiency as well as reducing environmental pollution.

\section{MATERIALS AND METHODS}

The soil used in this study was a sandy loam of Typic Paleudults (Bekenu Series) taken from University Putra Malaysia, Bintulu Sarawak Campus. The soil samples taken at $0-15 \mathrm{~cm}$ depth were air dried and ground to pass a $2 \mathrm{~mm}$ sieve. The selected chemical and physical properties of the soil were determined using standard procedures. The soil $\mathrm{pH}$ was determined in a 1:2.5 of soil: distilled water suspension and $1 \mathrm{M} \mathrm{KCl}$ using a glass electrode. Soil organic carbon was determined as $58 \%$ of the total loss of weight on ignition $^{[10]}$. The hydrometer method was used to determine soil texture ${ }^{[11]}$. The leaching method was used to determine cation exchange capacity ${ }^{[12]}$. The exchangeable cations ( $\mathrm{K}, \mathrm{Ca}, \mathrm{Na}$ and $\mathrm{Mg}$ ) were determined by the double acid method ${ }^{[13]}$. Total $\mathrm{N}$ was determined using Kjedhal method.

HA and FA used in this study were isolated using the method described by Stevenson ${ }^{[14]}$ with some modifications ${ }^{[15,16]}$. The extraction and fractionation periods used was $24 \mathrm{~h}$. HA and FA were isolated using $0.05 \mathrm{M} \mathrm{KOH}$ and $6 \mathrm{~N} \mathrm{H}_{2} \mathrm{SO}_{4}$ respectively. Total organic carbon was determined using the loss on ignition method ${ }^{[10]}$. The carboxylic- $\mathrm{COOH}$, phenolic$\mathrm{OH}$ functional groups and total acidity were determined using the method described by Inbar et al. ${ }^{[17]}$. The $\mathrm{E}_{4} / \mathrm{E}_{6}$ was determined using $\mathrm{E}_{4} / \mathrm{E}_{6} \mathrm{ratio}^{[14]}$. The solid HA was ground to pass $250 \mu \mathrm{m}$ and the urea was in granular form. FA and acidified (HA+FA) were in liquid form.

The treatments were: (i) Soil alone (T0); (ii) $2.02 \mathrm{~g}$ urea without additives (T1); (iii) $2.02 \mathrm{~g}$ urea $+0.75 \mathrm{~g}$ HA (T2); (iv) $2.02 \mathrm{~g}$ urea + 60 mL FA (T3); (v) $2.02 \mathrm{~g}$ urea $+60 \mathrm{~mL}$ acidified (HA+FA) (T4). The quantity of urea used was based on the standard recommendation for mature oil palms grown on Bungor Series (Typic Kandiudults) in Malaysia. The amounts of HA used were based on earlier unpublished laboratory trials that gave better mixtures. Treatment 2 was prepared by mixing $2.02 \mathrm{~g}$ urea with $0.75 \mathrm{~g}$ HA. Treatment 3 was prepared by mixing $2.02 \mathrm{~g}$ urea with $60 \mathrm{~mL} \mathrm{FA}$, while T4 was prepared by mixing $2.02 \mathrm{~g}$ urea with $60 \mathrm{~mL}$ acidified HA and FA. Afterwards, the treatments were transferred into a set of plastic vials, tightly closed and shaken using a reciprocal shaker at $150 \mathrm{rpm}$ for $30 \mathrm{~min}$ to ensure they were uniformly mixed.

Daily ammonia loss was measured for 15 days using the closed-dynamic air flow system method ${ }^{[5]}$. The system consisted of an exchange chamber $(500 \mathrm{~mL}$ Erlenmeyer flask) and a trap (250 mL Erlenmeyer flask), both stoppered and fitted with an inlet/outlet. The inlet of the chamber was connected to an air pump and the outlet was connected by polyethylene tubing to the trap containing boric acid solution. Soil weighing $250 \mathrm{~g}$ was placed in the exchange chamber and moistened to $60 \%$ field capacity.

The treatments were applied to the soil surface. Air was passed through the chambers at a rate of $2.75 \mathrm{~L}^{-1} \mathrm{~min}^{-1}$ chamber ${ }^{-1}$ and released $\mathrm{NH}_{3}$ captured in the trapping solution containing $75 \mathrm{~mL}$ boric acid, bromocresol green and methyl red indicator. The incubation chambers were maintained at room temperature. Boric acid indicator traps were replaced every $24 \mathrm{~h}$ and back-titrated with $0.01 \mathrm{~N} \mathrm{HCl}$, to estimate the $\mathrm{NH}_{3}$ released. Measurement was continued until the loss declined to $1 \%$ of the $\mathrm{N}$ added in the urea $^{[5,7,8]}$. After 15 days of incubation, soil samples were evaluated for $\mathrm{pH}$, exchangeable $\mathrm{NH}_{4}$ and available $\mathrm{NO}_{3}$.

The experimental design was a randomized complete block design with 3 replications for each treatment. Analysis of variance (ANOVA) was conducted to test for treatment effect while means of treatments were compared using Tukey's test ${ }^{[18]}$.

\section{RESULTS}

The selected chemical properties of soil (Table 1) were typical of the Bekenu Series and were consistent with those reported by Paramanathan ${ }^{[19]}$ except for the high values of $\mathrm{pH}$, organic carbon, CEC and exchangeable calcium which may be due to soil liming. The $\mathrm{pH}$ of urea was high as expected. The carbon, carboxylic, phenolic, total acidity and $\mathrm{E}_{4} / \mathrm{E}_{6}$ values of the HA were within the range reported by ${ }^{[14,20]}$. 
Am. J. Environ. Sci., 5 (3): 382-386, 2009

Table 1: Some chemical and physical characteristics of soil, urea, HA, FA and acidified (HA + FA)

\begin{tabular}{|c|c|c|c|c|c|}
\hline Property & Soil & Urea & HA & FA & $\begin{array}{l}\text { Acidified } \\
(\mathrm{HA}+\mathrm{FA})\end{array}$ \\
\hline $\mathrm{pH}$ (water) & 6.32 & 8.06 & nd & 1.13 & 1.00 \\
\hline $\mathrm{pH}(1 \mathrm{~N} \mathrm{KCl})$ & 5.52 & nd & nd & nd & nd \\
\hline Total organic carbon $(\%)$ & 4.72 & nd & 54.95 & nd & nd \\
\hline Nitrogen $(\%)$ & 0.17 & nd & nd & nd & nd \\
\hline $\operatorname{CEC}\left(\mathrm{cmol} \mathrm{kg}^{-1}\right)$ & 13.3 & $\mathrm{a}$ & nd & nd & nd \\
\hline Exchangeable $\mathrm{K}\left(\mathrm{cmol} \mathrm{kg}^{-1}\right)$ & 0.18 & nd & nd & nd & nd \\
\hline Exchangeable $\mathrm{Ca}\left(\mathrm{cmol} \mathrm{kg}^{-1}\right)$ & 1.21 & nd & nd & 0.89 & nd \\
\hline Exchangeable $\mathrm{Na}\left(\mathrm{cmol} \mathrm{kg}^{-1}\right)$ & 0.01 & nd & nd & 2.78 & nd \\
\hline Exchangeable $\mathrm{Mg}\left(\mathrm{cmol} \mathrm{kg}^{-1}\right)$ & 0.12 & nd & nd & 0.29 & nd \\
\hline Texture & LS & nd & nd & nd & nd \\
\hline Carboxylic group $\left(\mathrm{cmol} \mathrm{kg}^{-1}\right)$ & nd & nd & 538.81 & nd & nd \\
\hline Phenolic group $\left(\mathrm{cmol} \mathrm{kg}^{-1}\right)$ & nd & nd & 293.89 & nd & nd \\
\hline Total acidity $\left(\mathrm{cmol} \mathrm{kg}^{-1}\right)$ & nd & nd & 832.70 & nd & nd \\
\hline $\mathrm{E}_{4} / \mathrm{E}_{6}$ & nd & nd & 8.02 & nd & nd \\
\hline
\end{tabular}

Table 2: Total amounts of ammonia loss, $\mathrm{pH}$, exchangeable ammonium and available nitrate over 15 days of incubation

\begin{tabular}{lllll}
\hline Treatments & $\mathrm{NH}_{3}(\%)$ & $\mathrm{pH}\left(\mathrm{H}_{2} 0\right)$ & $\mathrm{NH}_{4}(\mathrm{ppm})$ & $\mathrm{NO}_{3}(\mathrm{ppm})$ \\
\hline T0 & $0.00^{\mathrm{c}}$ & $6.7^{\mathrm{b}}$ & $81.73^{\mathrm{e}}$ & $11.68^{\mathrm{c}}$ \\
T1 & $48.21^{\mathrm{a}}$ & $7.9^{\mathrm{ab}}$ & $378.27^{\mathrm{d}}$ & $23.35^{\mathrm{c}}$ \\
T2 & $46.32^{\mathrm{a}}$ & $7.8^{\mathrm{b}}$ & $532.38^{\mathrm{c}}$ & $25.69^{\mathrm{c}}$ \\
T3 & $37.05^{\mathrm{b}}$ & $6.1^{\mathrm{c}}$ & $1167.50^{\mathrm{a}}$ & $112.08^{\mathrm{a}}$ \\
T4 & $0.00^{\mathrm{c}}$ & $2.9^{\mathrm{d}}$ & $672.48^{\mathrm{b}}$ & $53.71^{\mathrm{b}}$ \\
\hline
\end{tabular}

Note: Different alphabets (within column) indicate significant difference between means using Tukey's test at $\mathrm{P}=0.05$

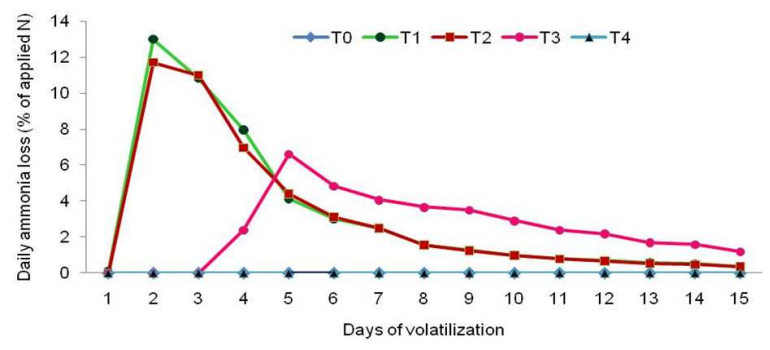

Fig. 1: Daily loss of ammonia from incubation

The $\mathrm{NH}_{3}$ loss started a day after incubation for $\mathrm{T} 1$, second day for $\mathrm{T} 2$, fourth day for $\mathrm{T} 3$ and no $\mathrm{NH}_{3}$ loss was found for $\mathrm{T} 0$ and $\mathrm{T} 4$ (Fig. 1). The maximum daily rate of $\mathrm{NH}_{3}$ loss for $\mathrm{T} 1(13 \%)$ and $\mathrm{T} 2(11.69 \%)$ was similar on the second day while the maximum $\mathrm{NH}_{3}$ loss for T3 was $6.61 \%$ and it occurred on day 5 of incubation. The decreasing trend after the maximum loss of ammonia for T1, T2 and T3 was similar until day 15 when the ammonia loss was about $1 \%$ of the $\mathrm{N}$ added in the form of urea.

The total amounts of $\mathrm{NH}_{3}$ lost, $\mathrm{pH}$, exchangeable ammonium and available nitrate at the end of the study are shown in Table 2. Urea with FA (T3) significantly reduced the total amount of $\mathrm{NH}_{3}$ loss compared to urea without additives (T1) while urea with acidified HA and FA (T4) had the greatest effect because there was no ammonia volatilization for 15 days of incubation. Urea with HA (T2) did not significantly reduce ammonia loss compared to the control (T1). The $\mathrm{pH}$ for $\mathrm{T} 2$ was not significantly different from $\mathrm{T} 1$ but significantly different from $\mathrm{T} 3$ and $\mathrm{T} 4$. This observation was consistent with those reported elsewhere ${ }^{[4-7]}$. Urea with additives caused significant accumulation of exchangeable ammonium compared to urea alone (Table 2). T3 and T4 had pronounced effect on available nitrate accumulation compared to other treatments (Table 2).

\section{DISCUSSION}

The low pH of HA and FA suggests that they were fully saturated with hydrogen ions during their fractionation via acidification using $6 \mathrm{~N} \mathrm{H}_{2} \mathrm{SO}_{4}$.

T3 and T3 significantly reduced ammonia volatilization because when urea is mixed with acidic material, the acidic product lowers the micro-site $\mathrm{pH}$, reduces the hydrolysis of urea thus causing a significant reduction in $\mathrm{NH}_{3}$. The low soil $\mathrm{pH}$ for $\mathrm{T} 3$ and $\mathrm{T} 4$ obtained in this study also confirms the study of Delaune and Patrick ${ }^{[21]}$ that urea hydrolyzes slowly when soil $\mathrm{pH}$ is less than 5.5 and lasted until it moves away from the acidified soil ${ }^{[4,21]}$. In this study, fulvic acid (T3) and acidified humic and fulvic acids (T4) which are acidic materials, acidified the soil, thus slowing urea hydrolysis. This may have effectively increased the volume of soil with which mixing of urea occurred and also increased the time required for complete hydrolysis. There was significant accumulation of exchangeable $\mathrm{NH}_{4}$ for $\mathrm{T} 2, \mathrm{~T} 3$ and $\mathrm{T} 4$ compared to urea alone suggesting its retention in these 3 treatments. The amount of available nitrate was significantly different for T3 and T4 compared to urea without additives but no significant difference for $\mathrm{T} 2$ suggesting that the retention of exchangeable ammonium for urea treatments with additives (T3 and T4) had profound effect on $\mathrm{NO}_{3}$ accumulation.

\section{CONCLUSION}

Humic acid alone was not effective in controlling ammonia volatilization even though ammonium retention was found to be significantly higher compared to urea alone. Fulvic acid significantly reduced ammonia volatilization by $23 \%$ compared to urea alone. It also caused the highest retention of ammonia and nitrate. However, there was no ammonia volatilization with acidified humic and fulvic acids (T4). Exchangeable ammonium and available nitrate 
accumulation under $\mathrm{T} 3$ was better than for $\mathrm{T} 4$. Ammonia loss could be reduced by improving exchangeable ammonium retention. It must be stressed that results obtained in the incubation experiment using an acidic $\left(\mathrm{pH}_{\text {water }} 6.32\right)$ soil of Bekenu series may only be applicable to similar acid soils. This may improve urea $\mathrm{N}$ use efficiency as well as reducing environmental pollution.

\section{ACKNOWLEDGMENT}

The researchers acknowledge the financial support of this research by the Ministry of Higher Education Malaysia.

\section{REFERENCES}

1. Ahmad, A., S. Ismail and S. Bhatia, 2003. Water recycling from Palm Oil Mill Effluent (POME) using membrane technology. Desalination, 157: 87-95. DOI: 10.1016/S0011-9164(03)00387-4

2. Suhaimi, M. and H.K. Ong, 2001. Composting empty fruit bunches of oil palm. Food Fertilizer Technology Center, Taiwan, Taipei. http://www.agnet.org/library/eb/505a/

3. O-Thong, S., P. Prasertsan, N. Intrasungkha, S. Dhamwichukorn and N.K. Birkeland, 2008. Optimization of simultaneous thermophilic fermentative hydrogen production and COD reduction from palm oil mill effluent by Thermoanaerobacterium-rich sludge. Int. J. Hydrogen Energy, 33: 1221-1231. DOI: 10.1016/j.ijhydene.2007.12.017

4. Fan, M.X. and A.F. Mackenzie, 1993. Urea and phosphate interactions in fertilizer microsites: Ammonia volatilization and $\mathrm{pH}$ changes. Soil Sci. Soc. Am. J., 57: 839-845. http://cat.inist.fr/?aModele $=$ afficheN\&cpsidt $=1132$ 5486

5. Siva, K.B., H. Aminuddin, M.H.A. Husni and A.R. Manas, 1999. Ammonia volatilization from urea as affected by tropical-based palm oil palm effluent (pome) and peat. Commun. Soil Sci. Plant Anal., 30: 785-804. DOI: 10.1080/00103629909370246

6. Stumpe, J.M., P.L.G. Vlek and W.L. Linday, 1984. Ammonia volatilization from urea and urea phosphates in calcareous soils. Soil Sci. Soc. Am. J., 48: 921-926. http://soil.scijournals.org/cgi/content/abstract/48/4/ 921
7. Ahmed, O.H., M.H.A. Husni, A.R. Anuar and M.M Hanafi, 2006. Effects of urea, humic acid and phosphate interactions in fertilizer microsites on ammonia volatilization and soil ammonium and nitrate contents. Int. J. Agric. Res., 1: 25-31. DOI: 10.3923/ijar.2006.25.31

8. Ahmed, O.H., M.H.A. Husni, A.R. Anuar and M.M. Hanafi, 2006. Reducing ammonia loss from urea and improving soil-exchange ammonium retention through mixing triple superphosphate, humic acid and zeolite. Soil Use Manage., 22: 315-319. DOI: $10.1111 / \mathrm{j} .1475-2743.2006 .00040 . x$

9. Brady, N.C. and R.R. Weil, 2002. The Nature and Properties of Soils.13 Edn., Prentice Hall, USA., ISBN: 0130167630, pp: 960.

10. Cheftez, B., P.G. Hatcher, Y. Hadar and Y. Chen, 1996. Chemical and biological characterization of organic matter during composting of municipal solid waste. J. Environ. Qual., 25: 776-785. http://jeq.scijournals.org/cgi/reprint/25/4/776

11. Tan, K.H., 2005. Soil Sampling, Preparation and Analysis. 2nd Edn., CRC Press, Taylor and Francis Group. Boca Raton, Florida, USA., ISBN: 0849334993.

12. Cottenie, A., 1980. Soil testing and plant testing as a basis of fertilizer recommendation. FAO Soils Bull., 38: 70-73. http://orton.catie.ac.cr/cgi$\mathrm{bin} / \mathrm{wxis}$.exe/?IsisScript=CATALCO xis\&method= post $\&$ formato $=2 \&$ cantidad $=1 \&$ expresion $=m f n=09$ 3537

13. Tan, K.H., 1996. Soil Sampling, Preparation and Analysis. Marcel Dekker, Inc., New York, ISBN: 0824796756, pp: 232-239.

14. Stevenson, F.J., 1994. Humus Chemistry: Genesis, Composition and Reactions, 2nd Edn., John Wiley and Sons, New York, ISBN: 9780471594741..

15. Ahmed, O.H., M.H.A. Husni, A.R. Anuar, M.M. Hanafi and E.D.S Angela, 2004. A modified way of producing humic acids from pineapple leaves. J. Sustain. Agric., 25: 129-139. DOI: 10.1300/J064v25n01_10

16. Susilawati, K., O.H. Ahmed, A.M. Nik Muhamad and M.Y. Khanif, 2007. Effects of extraction and fractionation period on the yield of a tropical peat soil (Hemists) humic acids. Am. J. Agric. Biol. Sci., 2: 202-205.

http://72.14.235.132/search?q=cache:VKPgcleSfq 8J:www.scipub.org/fulltext/AJAB/AJAB23202205.pdf+Effects+of+extraction+and+fractionation+ period+on+the+yield+of + a+tropical+peat+soil $+(\mathrm{H}$ emists + humic + acids $\& \mathrm{~cd}=1 \& \mathrm{hl}=\mathrm{en} \& \mathrm{ct}=\mathrm{clnk} \& \mathrm{gl}=\mathrm{pk}$ 
17. Inbar, Y., Y. Chen and Y. Hadar, 1990. Humic substances formed during the composting of organic matter. Soil Sci. Am. J., 54: 1316-1323. http://soil.scijournals.org/cgi/reprint/54/5/1316

18. SAS., 2001. SAS/STAT Software. SAS Institute, NC., ISBN: 1580258506.

19. Paramanathan, S., 2000. Soils of Malaysia: Their Characteristics and Identification, Vol. 1. Academy of Sciences Malaysia, Kuala Lumpur, ISBN: 9839445065 .
20. Tan, K.H., 2003. Humic Matter in Soil and the Environment: Principles and Controversies. 1st Edn., Mercel Dekker, Inc., New York., ISBN: 0824742729.

21. Delaune, R.D. and W.H. Patrick Jr., 1970. Urea conversion to ammonia in waterlogged soil. Soil Sci. Soc. Am. Proc., 34: 603-607. http://soil.scijournals.org/cgi/reprint/34/4/603 